\title{
Candidemia in Non-neutropenic Patients in a Pediatric Intensive Care Unit
}

\section{Bir Çocuk Yoğun Bakım Ünitesinde Nötropenik Olmayan Hastalarda Kandidemi}

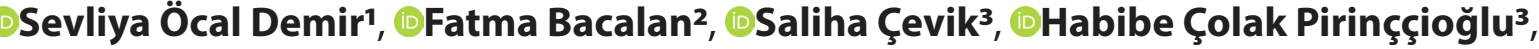 \\ -Mehmet Arda Kılınç4, - Leyla Tomar ${ }^{5}$ \\ 'Pediatric Infectious Disease, Department of Pediatric, İstanbul Medeniyet University Göztepe Prof. Dr. Süleyman Yalçın City Hospital, İstanbul, Turkey \\ 2Department of Medical Microbiology, Diyarbakır Children's Hospital, Diyarbakır, Turkey \\ ${ }^{3}$ Department of Infectious Disease and Clinical Microbiology, Diyarbakir Children's Hospital, Diyarbakır, Turkey \\ 4Pediatric Intensive Care Unit, Department of Pediatric, Başakşehir Çam and Sakura City Hospital, İstanbul, Turkey \\ 5Infection Control Nursing, Diyarbakır Children's Hospital, Diyarbakır, Turkey
}

\begin{abstract}
Aim: Candidemia has high morbidity and mortality rate in critically ill patients hospitalized in intensive care units. Prompt initiation of accurate anti-fungal therapy is essential for survival. In this study, a 6-year retrospective candidemia analysis of pediatric intensive care unit (PICU) was performed to review candida species distribution, risk factors for candidemia and change in the antifungal resistance in years.

Material and Method: The candidemia episodes of children older than 1 month followed in the PICU of Diyarbakır Children's Hospital between January 2014 and January 2020 were analyzed. The demographic and clinical characteristics, laboratory findings, treatments and outcomes of the patients were obtained from the medical records.

Results: In six years, 59 candidemia episodes were observed in 48 pediatric patients. Twenty-six of them female, median age at diagnosis was 43 months (range 1-225), median hospital stay was 48 days (range 3-664). All patients had received broad-spectrum antibiotics, majority had comorbidities (89.8\%), nasogastric tube (84.7), central venous catheter (78.0\%), and on mechanic ventilation (76.3\%). Type of candida species was identified in 36 episodes of candidemia; $47.2 \%$ of these episodes were caused by $C$. parapsilosis, $38,9 \%$ by C. albicans, $8.3 \%$ by C. glabrata (8.3\%), $2.8 \%$ by C. lusitaniae, and $2.8 \%$ by $C$. tropicalis. Length of hospital stay was longer among patients with nonalbicans candidemia $(p=0.02)$, whereas patients with albicans candidemia had higher leucocyte count at the diagnosis (0.006). The antifungal resistance was observed in the nonalbicans candidemia group, not in the albicans group $(p=0.017)$. Overall, thirty-day mortality rate was $16.9 \%$.

Conclusion: In the PICU when initiating empirical antifungal therapy for a critically ill patient, in the presence of a long hospital stay an agent has coverage for non-albicans candida that may have antifungal resistance should be selected.
\end{abstract}

Keywords: PICU, candida, candidemia, nonalbicans
Öz

Amaç: Kandidemi yoğun bakım ünitelerinde yatan kritik hastalarda yüksek morbidite ve mortalite oranına sahiptir. Sağ kalım için doğru anti-fungal tedavinin gecikmeden başlanmasının hayati önemi vardır. Bu çalışmada kandida türlerinin dağılımını, kandidemi için risk faktörlerini ve yıllar içinde anti-fungal dirençteki değişimi görmek için bir çocuk yoğun bakım ünites (ÇYBÜ)'inde gözlenen kandidemi ataklarının 6 yıllık retrospektif analizi yapıldı.

Gereç ve Yöntem: Ocak 2014- Ocak 2020 tarihleri arasında Diyarbakır Çocuk Hastalıkları Hastanesi ÇYBÜ'inde yatan 1 aydan büyük çocuk hastalarda gözlenen kandidemi atakları incelendi. Hastaların demografik ve klinik özellikleri, laboratuvar bulguları, tedavileri ve sonuçları tıbbi kayıtlarından elde edildi.

Bulgular: Altı yılda 48 çocuk hastada 59 kandidemi atağı izlendi. Hastaların 26'sı kız, tanı anındaki medyan yaş 43 ay (aralık 1-225), medyan hastanede kalış süresi 48 gün (aralık 3-664) idi. Hastaların tümü antibiyotik tedavisi almış, çoğunun komorbiditesi mevcut $(\% 89,8)$, nazogastrik tüp $(84,7)$, santral venöz kateter $(\% 78,0)$ kullanılmış ve mekanik ventilasyonda $(\% 76,3)$ izlenmişlerdi. Kandida türü 36 kandidemi epizodunda tanımlandı; \%47,2'sinde C. parapsilosis, \%38,9'unda C. albicans, \%8,3'ünde C. glabrata, \%2,8'inde C. lusitaniae ve \%2,8'inde C. tropicalis etkendi. Albicans kandidemili hastalarda tanı anında lökosit sayısı daha yüksek ( $p=0,006)$, non-albicans kandidemili hastalarda ise hastanede kalış süresi daha uzun idi $(p=0,02)$. Non-albicans candidemia grubunda anti-fungal direnç gözlenirken, albicans grubunda gözlenmedi $(p=0,017)$. Genel olarak, otuz günlük ölüm oranı \%16,9 idi.

Sonuç: ÇYBÜ'deki kritik hasta için ampirik antifungal tedavi başlarken, hastanın hastanede kalış süresi uzun ise antifungal direnci olabilen nonalbican kandidaları kapsayacak bir ajan seçilmelidir.

Anahtar Kelimeler: ÇYBÜ, kandida, kandidemi, nonalbikans

Corresponding (İletişim): Sevliya Öcal Demir, Istanbul Medeniyet University Goztepe Prof. Dr. Suleyman Yalcın City Hospital, Department of Pediatric, Pediatric Infectious Diseases Clinic, Eğitim Mah. Dr. Erkin Street., 34722, Istanbul, Turkey

E-mail (E-posta): sevliyademir@gmail.com

Received (Geliş Tarihi): 20.12.2020 Accepted (Kabul Tarihi): 17.03.2021 


\section{INTRODUCTION}

Candida species are significant pathogens for critically ill patients. ${ }^{[1]}$ It is the fourth most common cause of healthcare related bloodstream infections. ${ }^{[2]}$ Candidemia incidence was reported as 7 per 100,000 in infants under 1 year of age and 0.3 per 100,000 in children aged between 1 to 18 years by the 2017 United States' surveillance. ${ }^{[3]}$ In a study from our country, Turkey, the pediatric candidemia incidence was estimated as 2.9 per 1,000 admissions between 2013$2014 .{ }^{[4]}$

Candida albicans (C. albicans) is the most frequently isolated species, whereas nonalbicans species are increasingly isolated in recent years. ${ }^{[1,5,6]}$ The well-known factors that increase the risk for candidemia are prolonged hospital stay, broad-spectrum antibiotic usage, presence of comorbidities, immune suppression, mechanical ventilation, central venous catheter, parenteral nutrition, gastrointestinal perforation or operation, and renal failure which require hemodialysis. ${ }^{[5,7-9]}$ Mortality rate was reported as over $60 \%$ in untreated patients, in children with appropriate treatment this rate decreased to approximately 9 to $40 \% \cdot{ }^{[10,11]}$ In cases of high suspicion of invasive candidiasis, waiting for laboratory identification of candidemia is the time consuming and can increase mortality, early initiation of antifungal treatment will improve survival. ${ }^{[12,13]}$

Here, we retrospectively evaluated children with candidemia in term of clinical and laboratory characteristics to increase the awareness of physicians about disease and its management.

\section{MATERIAL AND METHOD}

This retrospective study included the patients with candidemia hospitalized in Diyarbakır Children's Hospital pediatric intensive care unit (PICU) between January 2014 and January 2020. The unit was working with its full capacity of 24 beds. Data about demographic and clinic characteristics of patients were collected from medical records and compared between patients with albicans candidemia and non-albicans candidemia, and also between patients followed before and after 2018.

The diagnosis of candidemia was made according to CDC/ NHSN surveillance definitions. ${ }^{[14]}$ If the blood culture from a patient was positive for same candida species in 30 days of first positive blood culture, this episode was not included to the study.

Blood specimens were incubated in BACTEC 9120 blood culture system (Becton Dickinson, USA). The media monitored for 5 days, when the automatic alert system signaled growth in any of the bottles, passages were performed from blood culture bottles to 5\% sheep blood agar, chocolate agar Eosin Methylene-blue Lactose Sucrose (EMB) medium, and Sabouraud dextrose agar (SDA, Oxoid, United Kingdom) and incubated at 37 for 18 to 24 hours. In addition, for identification and antifungal susceptibility tests, VITEK 2 Compact $^{\circledast}$ (bioMeriéux, France) system and identification cards (YST) were used. Antifungal susceptibility cards (ASTYST01) were used to investigate susceptibility to fluconazole, amphotericin B, voriconazole, caspofungin, micafungin and flucytosine. The results were made taking into account the EUCAST (European Committee on Antimicrobial Susceptibility Testing) recommendations. ${ }^{[15]}$

The statistical analyses were performed using SPSS Version 21.0 (IBM Corp. Released 2013. IBM SPSS Statistics for Windows, Version 21.0. Armonk, NY). Characteristics of patients, are described as $\mathrm{n}$ (percent) for categorical or median (min-max) for continuous variables, and were compared among test groups by using chi-square or MannWhitney tests, as appropriate. P values equal to or less than $5 \%$ were considered significant.

\section{RESULTS}

Fifty-nine candidemia episodes of 48 patients was included in study. Two patients had 3 episodes, 7 patients had 2 episodes, 39 patients had 1 episode of candidemia. The median time between two consecutive episodes in the same patient was 5,3 months (range 1.7-36.7). The median age at the diagnosis was 43 months (range 1-225). The median hospitalization time before candidemia was 48 days (range 3-664), all patients had used broad-spectrum antibiotics, \%89.8 had comorbidities, $84.7 \%$ had nasogastric tube, $78.0 \%$ had central venous catheters, $76.3 \%$ were on mechanic ventilation support (Table 1).

The number of candidemia episodes was $8,4,4,5,18,20$ for 2014, 2015, 2016, 2017, 2018, and 2019 respectively. The increase in the number of candidemia episodes was striking in last two years. When demographic and clinical characteristic of patients with candidemia before and after 2018 were compared, no statistically significant difference was found (Table 2).

Candida species identification was not performed in hospital until end of 2017, so in only 36 episodes identification was done; $47.2 \%$ of these episodes were caused by C. parapsilosis, $38,9 \%$ by C. albicans, $8.3 \%$ by C. glabrata ( $8.3 \%), 2.8 \%$ by C. lusitaniae, and $2.8 \%$ by C. tropicalis (Figure 1). We compared the characteristics of patient with C. albicans candidemia and patients with nonalbicans candidemia. In nonalbicans group hospitalization duration before candidemia was significantly longer, and in albicans group leucocyte count was higher at diagnosis, $\mathrm{p}=0.02, \mathrm{p}=0.006$ respectively (Table $\mathbf{1}$ ).

Antifungal susceptibility test was begun after half of 2018; in 26 episodes antifungal susceptibility tests were performed, all resistant candida species were non-albicans $(p=0.017)$; in 2017 one C. glabrata had resistance to fluconazole (intrinsic resistance), in 2018 no resistance was reported in 6 tests (0.0\%), in 20193 C. parapsilosis had resistance to voriconazole, 2 C. glabrata had resistance to caspofungin (27.8\%). 
Table 1. The demographic and clinical features of pediatric patients with candidemia in PICU of Diyarbakır Children's Hospital between 2014 and 2020

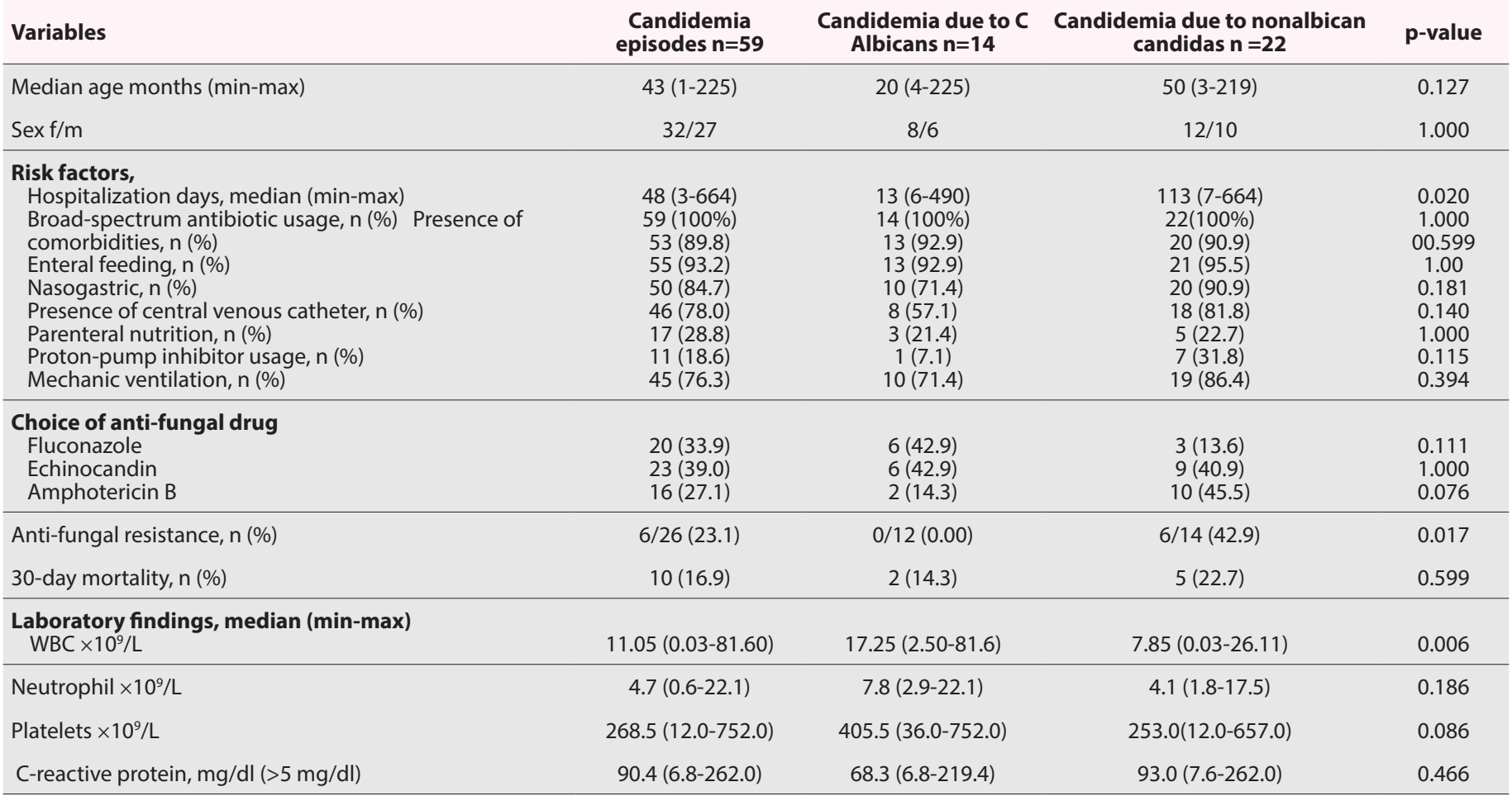

Table 2. The comparison of demographic and clinical features of pediatric patients with candidemia before and after 2018

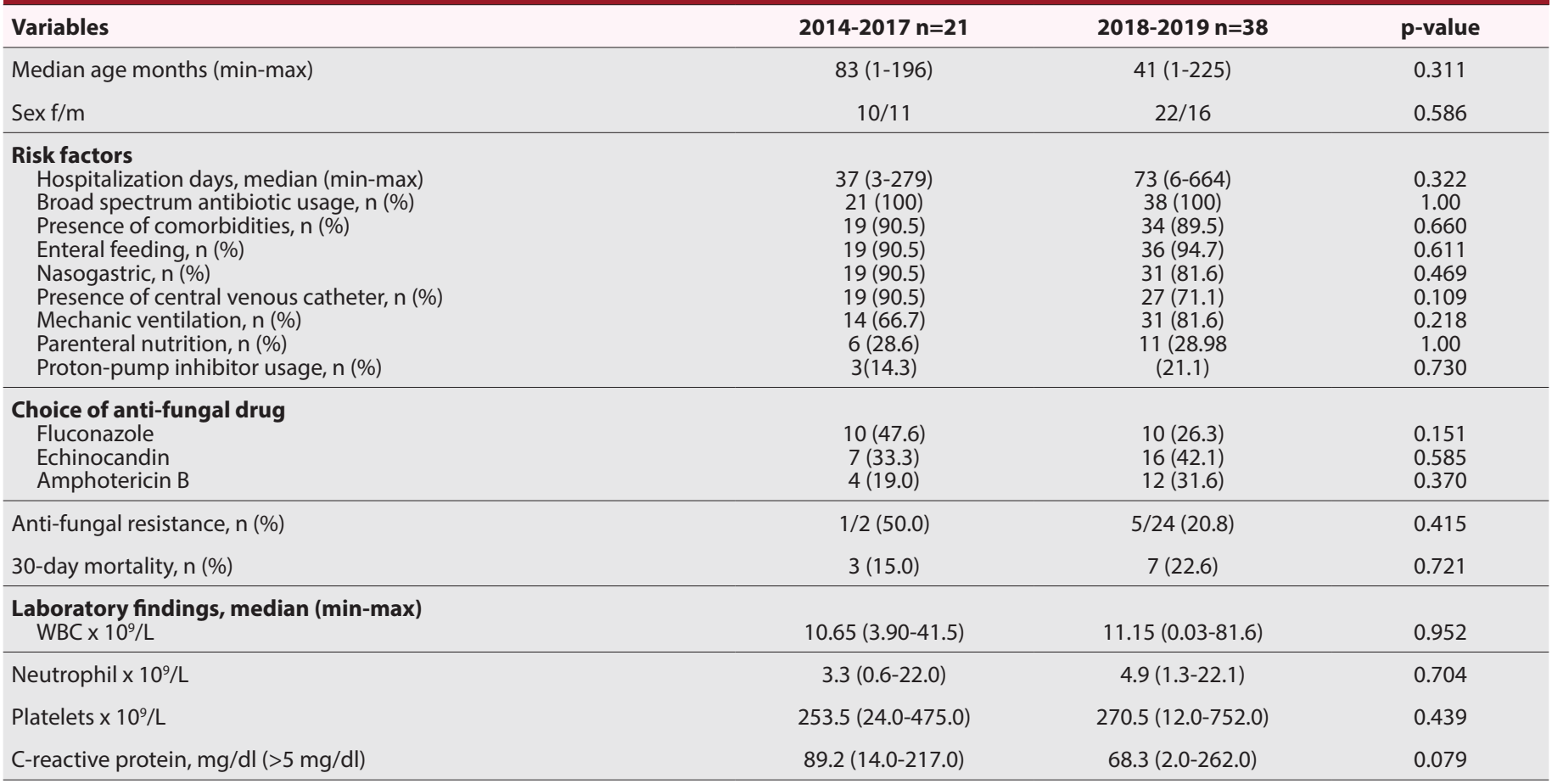

Invasive candidiasis was investigated with echocardiography (ECO), ophthalmic examination, and abdominal ultrasonography in 38 candidemia episodes of last two years and BOS examination was additionally performed in 8 of these episodes, but no any visceral involvement was detected. There were no data for patient diagnosed before 2018. The overall mortality rate of candidemia was $16.9 \%$ in this study, there was no statistically significant difference in mortality rate between the $C$. albicans and nonalbicans groups, and between candidemia episodes diagnosed before and after 2018. 


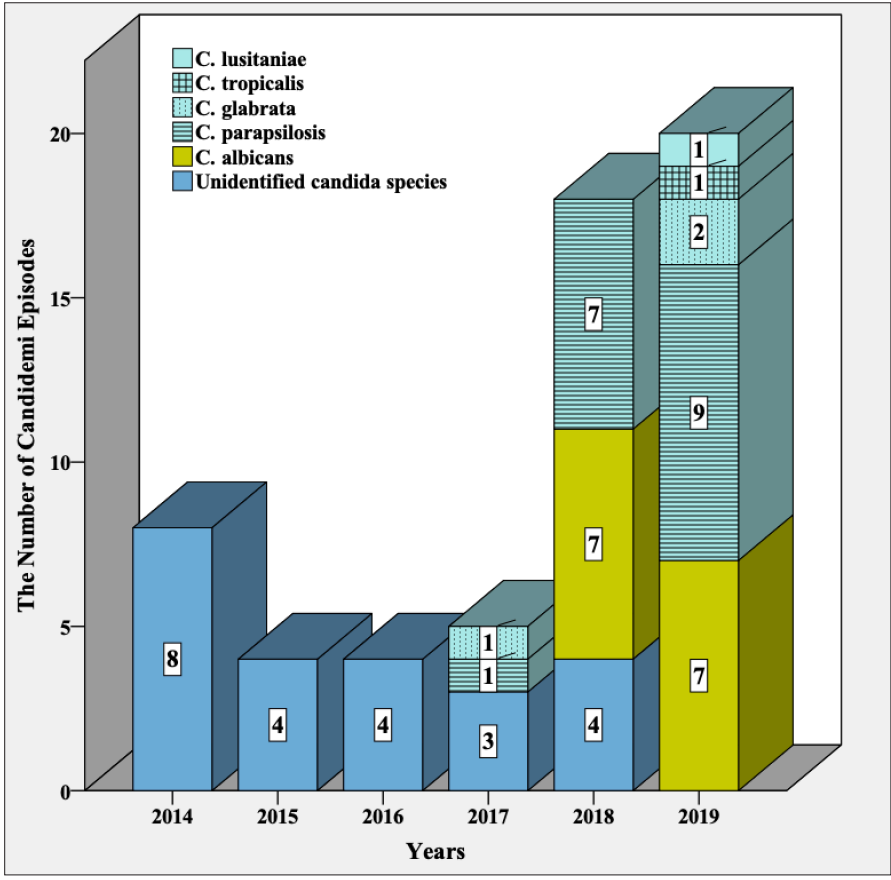

Figure 1. The candida species distribution in PICU of Diyarbakır Children's Hospital between 2014 and 2020

\section{DISCUSSION}

Candidemia has high morbidity and mortality rate in critically ill patients, timely initiation of accurate treatment is vital. Therefore, it is necessary to be aware of characteristic of disease, candida species distribution in unit and their antifungal resistance rate.

Incidence of fungal infections are increasing due to prolonged hospitalization and extensive use of broadspectrum antibiotics, immune suppressant agents, and chemotherapeutics. In our study the number of candidemia episodes were found significantly higher in last two years than previous years. Since we had no a control group without candidemia, we could not fully analyze reasons for this increase. Ulu Kilic et al. also found an increase in the annual incidence of candidemia in their study involving patients aged 0-88 years, and attributed this increase to worsening of patient profile, use of broad-spectrum antibiotic, increased frequency of major surgery, and severe underlying comorbidities of the patients. ${ }^{[16]}$ On the other hand, Mantadakis et al. reported decline in incidence of pediatric candidemia in United State and some other countries due to skin preparation with chlorhexidine before central catheter insertion, maintenance of bundles, meticulous catheter care and daily discussion of catheter necessity. ${ }^{[17]}$ They advise taking additional interventions aiming to reduce gut associated candidemia. Hovewer it is challenging to make comparison as the rates of candidemia in the units affected by characteristics of patients, infection control measures taken, the frequency of invasive procedures, and the principle of antibiotic administration.
The median age of our patients at the diagnosis was 43 months. Sutcu et al. evaluated epidemiologic characteristics of healthcare associated candida infections in children, including newborns, and reported mean age as 11 months, $13.4 \% \leq 1$ month, $50.7 \%$ between 1-24 months, 35.9\% >24 months old. ${ }^{[4]}$ An 11-year retrospective study analyzed 1395 candidemia episodes in children in Europe reported that of the $36.4 \%$ of episodes occurred in neonates, $13.8 \%$ in infants, and $49.8 \%$ in children and adolescents. ${ }^{[1]}$

Risk factors for candidemia are well defined in children, compatible with this our all patients had used broad-spectrum antibiotics, the majority were on mechanic ventilation support, had nasogastric tube and central venous catheter. Even though we think these risk factors have increased gradually over the years, we could not prove this due to absence of a control patient group without candidemia.

The distribution of Candida species varies geographically and temporally. Even tough C. albicans is the most commonly isolated species, nonalbicans species isolation is increasing. [1,5,6] C. parapsilosis is reported as the dominant nonalbicans species in children. ${ }^{[1,5,18]}$ In our PICU C. parapsilosis was the most frequently isolated candida species, and this appears to be related to the prolongation of hospital stay. Ulu Kılıç et al. reported same relation in adult patients, additionally they found high frequency of central venous catheter usage in nonalbicans candidemia. ${ }^{[16]}$ Two other studies from Turkey stated higher use of central venous catheters and total parenteral nutrition (TPN) in C. parapsilosis candidemia. ${ }^{[19,20]}$ In adults, the predominant nonalbicans candida is C. parapsilosis in Asia, Southern Europe, and South America, whereas it is the C. glabrata in northern Europe, Canada and United States. ${ }^{[21]}$

Positive blood culture is the gold-standard test for diagnosing of candidemia, but its overall sensitivity is about $50 \%$. $^{[22]}$ So, non-culture methods like antigen, antibody, $\beta$-D-glucan detection assays, and polymerase chain reaction (PCR) are increasingly used. None of these tests were available in our institution. We compare non-specific laboratory test results between albicans and nonalbicans candidemia groups, leucocyte count was found higher in albicans group. Actually, clinical value of this finding is not well established, it may demonstrate acute septic clinic in $C$ albicans candidemia. There are few studies compared leucocyte count between two groups. Cheng et al. reported that the leukocyte count was high, $\geq 15,000 / \mathrm{mm}^{3}$, in the albicans group, and neutropenia was more common in the non-albicans group. ${ }^{[25]}$ It has been reported in many studies that non-albicans candidemia is more common in neutropenic patients. ${ }^{[23,24]}$ After clinical value of this finding supported with the large-scale studies, leukocytosis can be used as a sign of albicans candidemia in suspicion of candidemia or if candida type is not yet been identified.

Besides being aware of candida species distribution in unit, knowing anti-fungal resistance rate can help to choose accurate antifungal treatment. In our institution antifungal 
resistance tests begun to be performed in the second half of 2018. While there was no resistance in 2018, in 2019 estimated resistance rate for voriconazole was $16.7 \%$, for echinocandins was $11,1 \%$. Previous studies from Turkey reported no resistance for echinocandins and $7.5 \%$ for fluconazole. [16,19] The high antifungal resistance rate of our PICU may be related to widespread usage of echinocandins. In fact, in our institution generally the 2012 European Society for Clinical Microbiology and Infectious Diseases (ESCMID) and 2016 Infectious Diseases Society of America (IDSA) guidelines were followed for treatment of candidiasis in children. ${ }^{[26,27]}$ Empiric antifungal therapy was initiated when critically ill children had risk factors for candidiasis and if the fever persist despite the use of appropriate antibiotics. Echinocandins were the drugs of choice for those with moderate to severe disease. Although culture antibiogram revealed fluconazole susceptibility, hesitating to switch to step down therapy with fluconazole may be one of the reasons for high echinocandins resistance in ours PICU. So, use of stepdown antifungal treatment in susceptible type of candida seems essential.

Data about the investigation of candidemia complications, such as deep-seated infection, were reached for the last two years. Absence of complications in our patients may be due to small size of our study or due to rarity of these complications such as ocular involvement reported as 3.2\%.[28]

Mortality rate of candidemia was roughly $47 \% .{ }^{[26]}$ In this study it was $16.9 \%$, there was no statistical difference between $C$. albicans and non-albicans group, and between candidemia episodes diagnosed before and after 2018.

Even though sample size of study is small, candida species identification and anti-fungal resistance tests have begun to performed lately in a limited number of cases, it is still valuable, because it evaluates candidemia in pediatric age group.

\section{CONCLUSION}

Antifungal treatment should not be delayed in critically ill patients who have risk factors for candidiasis and with ongoing fever despite appropriate antibiotic use. For patients with long hospital stay empiric antifungal treatment should cover non-albicans candida which may have antifungal resistance. Patients should be monitored for clinical response to antifungals, if antibiogram show susceptibility switching to step down antifungal treatment should be considered. This may prevent antifungal resistance in institution.

\section{ETHICAL DECLARATIONS}

Ethics Committee Approval: This study was approved by the decision of Clinical Research Ethics Committee of Health Sciences University Diyarbakır Gazi Yaşargil Training and Research Hospital with the number of 283, Jun 14, 2019,

Informed Consent: Because the study was designed retrospectively, no written informed consent form was obtained from patients
Referee Evaluation Process: Externally peer-reviewed.

Conflict of Interest Statement: The author(s) declared no potential conflicts of interest with respect to the research, authorship, and/or publication of this article.

Financial Disclosure: The authors declared that this study has received no financial support.

\section{REFERENCES}

1. Warris A, Pana ZD, Oletto A, et al. Etiology and Outcome of Candidemia in Neonates and Children in Europe: An 11-year Multinational Retrospective Study. Pediatr Infect Dis J 2020; 39 (2):114-20.

2. Wisplinghoff $\mathrm{H}$, Bischoff $\mathrm{T}$, Tallent SM, Seifert H, Wenzel RP, Edmond MB. Nosocomial bloodstream infections in US hospitals: analysis of 24,179 cases from a prospective nationwide surveillance study. Clin Infect Dis 2004; 39 (3):309-17.

3. Tsay SV, Mu Y, Williams S, et al. Burden of Candidemia in the United States, 2017. Clin Infect Dis 2020; 71 (9): e449-53.

4. Sutcu M, Salman N, Akturk H, Dalgıc N, Turel O, Kuzdan C, et al. Epidemiologic and microbiologic evaluation of nosocomial infections associated with Candida spp in children: A multicenter study from Istanbul, Turkey. Am J Infect Control. 2016; 44 (10):1139-43.

5. Benedict K, Roy M, Kabbani S, et al. Neonatal and Pediatric Candidemia: Results from Population-Based Active Laboratory Surveillance in Four US Locations, 2009-2015. J Pediatric Infect Dis Soc 2018; 7 (3):e78-85.

6. Lausch KR, Schultz Dungu KH, Callesen MT, et al. Pediatric Candidemia Epidemiology and Morbidities: A Nationwide Cohort. Pediatr Infect Dis J 2019;38 (5):464-9.

7. Playford EG, Marriott D, Nguyen Q, et al. Candidemia in nonneutropenic critically ill patients: risk factors for non-albicans Candida spp. Crit Care Med. 2008;36 (7):2034-9.

8. Zaoutis TE, Prasad PA, Localio AR, et al. Risk factors and predictors for candidemia in pediatric intensive care unit patients: implications for prevention. Clin Infect Dis. 2010;51:e38.

9. Pana ZD, Kotzadamis D, Roilides E. Invasive Candidiasis in Pediatric Intensive Care Unit: More Challenges. Pediatr Infect Dis J. 2018;37 (12):1309-11.

10. Andes DR, Safdar N, Baddley JW, et al. Impact of treatment strategy on outcomes in patients with candidemia and other forms of invasive candidiasis: a patient-level quantitative review of randomized trials. Clin Infect Dis. 2012;54 (8):1110-22.

11. Dutta A, Zaoutis TE, Palazzi DL. An update on the epidemiology of candidemia in children Curr Fungal Infect Rep. 2012;6:296.

12. Garey KW, Rege M, Pai MP, et al. Time to initiation of fluconazole therapy impacts mortality in patients with candidemia: a multi-institutional study. Clin Infect Dis 2006; 43 (1):25-31.

13. Kollef M, Micek S, Hampton N, Doherty JA, Kumar A. Septic shock attributed to Candida infection: importance of empiric therapy and source control.Clin Infect Dis 2012;54 (12):1739-46.

14. Horan TC, Andrus M, Dudeck MA. CDC/NHSN surveillance definition of health care-associated infection and criteria for specific types of infections in the acute care setting. Am J Infect Control 2008;36 (5):309-32.

15. Shin JH, Kim MN, Jang SJ, et al. Detection of amphotericin B resistance in Candida haemulonii and closely related species by use of the Etest, Vitek-2 yeast susceptibility system, and CLSI and EUCAST broth microdilution methods. J Clin Microbiol 2012; 50 (6):1852-5.

16. Ulu Kilic A, Alp E, Cevahir F, Ture Z, Yozgat N. Epidemiology and cost implications of candidemia, a 6-year analysis from a developing country. Mycoses 2017; 60 (3):198-203.

17. Mantadakis E, Pana ZD, Zaoutis T. Candidemia in children: Epidemiology, prevention and management. Mycoses. 2018; 61 (9): 614-22. 
18. Palazzi DL, Arrieta A, Castagnola E, et al. Candida speciation, antifungal treatment and adverse events in pediatric invasive candidiasis: results from 441 infections in a prospective, multi-national study. Pediatr Infect Dis J. 2014;33(12):1294-6.

19. Kazak E, Akin H, Ener B, et al. An investigation of Candida species isolated from blood cultures during 17 years in a university hospital. Mycoses. 2014;57(10):623-9.

20. Gürcüoglu E, Ener B, Akalın $H$, et al. Epidemiology of nosocomial candidaemia in a university hospital: a 12 year study. Epide-miol Infect. 2010;138(9):1328-35.

21. Kullberg BJ, Arendrup MC. Invasive Candidiasis.N Engl J Med. 2015;373 (15):1445-56.

22. Clancy CJ, Nguyen MH. Finding the "missing 50\%" of invasive candidiasis: how nonculture diagnostics will improve understanding of disease spectrum and transform patient care. Clin Infect Dis 2013; 56 (9):1284-92.

23. Leroy O, Mira JP, Montravers P, Gangneux JP, Lortholary O, AmarCand Study Group. Comparison of albicans vs. non-albicans candidemia in French intensive care units. Crit Care.2010; 14(3):R98.

24. Ghanem-Zoubi N, Khoury J, Arnon M, Zorbavel D, Geffen Y, Paul M. Risk Factors for Non-Albicans Candidemia Focusing on Antifungal and Immunosuppresive Therapy. Isr Med Assoc J. 2019; 21(5):303-7.

25. Cheng MF, Yang YL, Yao TJ, Lin CY, Liu JS, Tang RB, et al. Risk factors for fatal candidemia caused by Candida albicans and non-albicans Candida species. BMC Infect Dis. 2005; 5:22.

26. Hope WW, Castagnola E, Groll AH, et al. ESCMID* guideline for the diagnosis and management of Candida diseases 2012: prevention and management of invasive infections in neonates and children caused by Candida spp. Clin Microbiol Infect. 2012;18 Suppl 7:38.

27. Pappas PG, Kauffman CA, Andes DR, et al. Clinical Practice Guideline for the Management of Candidiasis: 2016 Update by the Infectious Diseases Society of America. Clin Infect Dis. 2016;62 (4):e1-50.

28. Fierro JL, Prasad PA, Fisher BT, et al. Ocular manifestations of candidemia in children. Pediatr Infect Dis J. 2013;32 (1):84-6. 